\title{
Application of Chemmo Configuration Play as a Learning Media of Elements Periodic System
}

\author{
Achmad Lutfi \\ dept. of Chemistry \\ Universitas Negeri Surabaya \\ Surabaya, Indonesia \\ achmadlutfi@unesa.ac.id
}

\author{
Rusly Hidayah \\ dept. of Chemistry \\ Universitas Negeri Surabaya \\ Surabaya, Indonesia
}

\author{
Muslela Qona'atun \\ dept. of Chemistry \\ Universitas Negeri Surabaya \\ Surabaya, Indonesia
}

\begin{abstract}
This study aims to determine the effect of using the Chemmo Configuration game that has been developed based on pedagogical requirements and game requirements as a learning medium. The form of research used was PreExperimental Research with the design of a single group One Group Pretest-Posttest Design conducted on grade $X$ students in one of the high schools in East Java, Indonesia. Before learning the Periodic System the Element is done prestest and after learning the posttest is done, giving questionnaires as motivation, and giving questionnaires to students' responses. The results showed that the learning outcomes of students using the Chemmo Configuration game were classified as good with a percentage of classical completeness of $100 \%$ and student motivation to achieve a percentage of $95.30 \%$ with a high category. It was concluded that the use of the Chemmo Configuration game that was developed based on pedagogical requirements as a learning media for the Periodic System of Elements can change student learning outcomes to be classically complete and make students' learning motivation high. On this basis, computer games with a pedagogic and permanence requirements as learning media should be developed as learning media to meet the needs of the game as a medium for learning chemistry.
\end{abstract}

Keywords-Games, Chemmo Configuration, Elemental Periodic System, Pedagogic.

\section{INTRODUCTION}

The periodic system of elements is one of the chemical materials taught at the Senior High School level. In this material students are required to be able to know the principles and rules of writing electron configurations, write electron configurations in the form of orbital diagrams, determine the location of an element in the periodic table of elements based on electron configurations, and analyze the relationship between atomic numbers with the periodicity of elements. With such material characteristics, it is not uncommon for students to still have difficulties when determining the location of elements in the periodic table of elements and the periodic nature of elements, so that students' mastery of the material periodic system is still low [1]. This material can also be make receiving information less effective on long-term memory students, so that understanding of the material is easily lost and forgotten [2]. In addition, the periodic material system of elements is considered difficult for students because of the many concepts that must be understood such as the radius of the atom, electronegativity and similarity of other elements, these difficulties make students less motivated in learning [3].

The initial research activity carried out at one of East Java High Schools shows that $70 \%$ of students consider the periodic material of the element as a chemical material that is classified as difficult and considered unattractive. Meanwhile the results of interviews with chemistry teachers, showed if students had difficulty determining the electron configuration because they forgot about the order of the energy levels of quantum numbers. Learning media that are used are still more often using powerpoints and blackboards, for the use of instructional media such as computer or Android games are rarely applied. Motivation of learning of students in learning chemistry is also fairly low so that this also impacts on student learning outcomes, for that there needs to be an effort to motivate students to continue to learn the periodic system material so that it has a positive impact on learning outcomes.

One effort that can be done is the use of instructional media that can attract the attention of students so as to make students motivated to learn. As the development of science and technology, the use of instructional media is also experiencing growth, one of which is the use of computerbased games as a medium in learning. The use of computerized games will attract more attention of students and make them tend to have a better memory of what they have learned because they are actively involved in the game [1]. The use of games in chemistry learning can also motivate students, improve their ability to make decisions and make students make use of actively learned knowledge [4]. Good motivation during the learning process will give good results [5]. According to Lutfi [11] that the development of computerized games as learning media must pay attention to pedagogical aspects and aspects of game requirements.

The use of games as a medium for learning chemistry can actively involve students, focus attention, provide positive motivation and be able to entertain students [6]. There is now a computerized Chemmo Configuration game designed for the learning of chemistry of the periodic elemental system. The game is already suitable for use as a learning medium for chemicals. The periodic system of the elements developed has fulfilled the pedogogical and game requirements Chemmo Configuration is an adventure- 
themed game in the forest. This game consists of four levels. At every level of the game there are challenges that must be faced by players, at the end of the level there will be chemical problems related to the material Periodic system of elements that must be answered by the player in order to advance to the next level.

The use of the Chemmo Configuration game in learning is intended to test the computerized game that has been developed based on pedagogical requirements and game requirements, whether it can have a positive impact on student learning outcomes and learning motivation [11].

\section{METHODS}

The research method used in this research is experimental research. The form of research used is PreExperimental Research with the design of a single group One Group Pretest-Posttest Design. This research was conducted to class $\mathrm{X}$ one of high schools in East Java. Students are given a pretest sheet to find out the students' initial understanding of the Element Periodic System material, then students are given treatment namely learning the Periodic System learning using the Chemmo Configuration game as a learning medium.

After using the Chemmo Configuration game as a learning medium, each student is given a posttest sheet, a motivation questionnaire and a student questionnaire response to the use of the Chemmo Configuration game as a learning media on the Periodic Element Material. To find out individual completeness, the following formula is used.

$$
\text { Individual completeness }=\frac{\text { score }}{\text { total score }} x 100 \%
$$

For classical completeness calculated by the following formula.

$$
\text { Classical completeness }=\frac{\text { ¿students are complete }}{\sum \text { total students }} x 100 \%
$$

Individual learning completeness is determined by a value of KK78 according to the KKM determined by the school and classical completeness is set at $\geq 85 \%$ [7]. To test whether there is a difference in the scores of the prestest and posttest is done by paired t test with the help of the SPSS program. Expressed significantly different if the price of $t$ calculated is greater than the price of $t$ table at $1 \%$ level of signification.

The results of the response questionnaire can be calculated using the formula.

$$
\% \text { Response }=\frac{\text { Total score of each statement }}{\text { Sum of response }} \times 100 \%
$$

While the results of the student learning motivation questionnaire can be calculated using the formula:

$\%$ Learning motivation $=\frac{\text { Total score of each statement }}{\text { Sum of response }} \times 100 \%$

\section{RESULTS AND DISCUSSION}

Based on research that has been done, presented the results of research and discussion of the influence of the Chemmo Configuration game as a learning media on the Material Periodic System material on learning outcomes and student motivation.

\section{A. Student Learning Outcomes Data}

Student learning outcomes data obtained from the provision of pretest and posttest sheets. Pretest question sheets are given before students learn to use the Chemmo Configuration game, while posttest question sheets are given after students use the game. Students are declared complete when their scores meet the KKM or $\geq 78$. The following are the results of the students' pretest and posttest.

TABLE 1. PRETEST AND POSTTEST RESULTS

\begin{tabular}{llllllll} 
Score & $\begin{array}{l}\text { Sig } \\
\text { Kolmo } \\
\text { gorov- } \\
\text { Smir } \\
\text { nov Z }\end{array}$ & $\begin{array}{l}\text { Con } \\
\text { Clu } \\
\text { sion }\end{array}$ & $\begin{array}{l}\text { Ave } \\
\text { rage }\end{array}$ & $\begin{array}{l}\text { t- } \\
\text { paired }\end{array}$ & & & \\
df & $\begin{array}{l}\text { t-ta } \\
\text { ble }\end{array}$ & $\begin{array}{l}\text { Con } \\
\text { Clu } \\
\text { sion }\end{array}$ \\
\hline Pre & 0,073 & & 33,79 & & & & Ho \\
Test & & & & & & & $\begin{array}{l}\text { reje } \\
\text { cted, } \\
\text { Post }\end{array}$ \\
Tes & 0,091 & Normal & 87,47 & 14,82 & 27 & 2,47 & Ha \\
& & & & & & & $\begin{array}{l}\text { accep } \\
\text { ted. }\end{array}$ \\
\hline
\end{tabular}

Based on Table I shows the pretest score and posttest score are normally distributed because the sig price is greater than 0.05 so it can be tested by paired t test and obtained $t$ count value is 14.82 greater than the table price (2.47) means $\mathrm{Ho}$ is rejected and $\mathrm{Ha}$ is accepted. This means that there is a significant difference between the average score of the pretest and the average posttest score. The results show the learning of the Periodic System of Elements using the Chemmo Configuration game can improve learning outcomes. If we look at mastery learning after learning presented in Table II, it also shows an increase.

TABLE II. COMPLETION OF LEARNING OUTCOMES

\begin{tabular}{lcc}
\hline & $\begin{array}{l}\text { Pretest } \\
\text { Complete }\end{array}$ & $\begin{array}{l}\text { Posttest } \\
\text { Complete }\end{array}$ \\
\hline $\begin{array}{l}\text { Number of individual } \\
\text { completeness }\end{array}$ & 4 & 28 \\
Classical completeness (\%) & $14,28 \%$ & $100 \%$ \\
\hline
\end{tabular}

Based on Table 2 above, there were only 4 students who completed the pretest score, while the other 24 students did not complete because they had a pretest score below the $\mathrm{KKM}$, for that the classical completeness pretest score obtained was $14.28 \%$. Meanwhile the posttest score showed better results where 28 students were declared complete because the scores met the KKM, so the percentage of classical completeness was $100 \%$. There are students who are incomplete on the pretest scores because they have never learned the Element Periodic System material and some have been able to achieve completion because at the junior high school level the upper structure of the material is taught and the students are categorized as smarter than other students. Based on these results there is a positive influence 
on student learning outcomes after using the Chemmo Configuration game as a learning media on the Material Periodic System material. These results are in line with research by Lutfi et al which states that student learning outcomes have improved after using games as a learning medium and making students feel learning chemistry is fun [8].

\section{B. Results of Student Learning Motivation Questionnaire}

Data on the results of students 'learning motivation questionnaires are used to find out how students' motivation to learn after using the Chemmo Configuration game as a learning medium on the Material Periodic System material. The following are the results of the students' learning motivation questionnaire.

TABLE III. MOTIVATION QUESTIONNAIRE RESULTS

\begin{tabular}{cc}
\hline Assessed Indicator & $\begin{array}{c}\text { Average } \\
\text { Percentage }\end{array}$ \\
\hline Competitive Motivation & $91,71 \%$ \\
Motivation to Work Hard & $100 \%$ \\
Motivation to move forward & $96 \%$ \\
\hline
\end{tabular}

The first indicator is to determine the students' motivation to compete with their friends in playing the Chemmo Configuration game as a learning media on the Material Periodic System material, obtaining a percentage of $91.71 \%$. These results indicate if the average student has the motivation to compete when playing the Chemmo Configuration game.

The second indicator aims to find out the motivation of students to work hard in completing tasks given in the Chemmo Configuration game, obtaining a percentage of $100 \%$. This is shown by the attitude of students who try to read the material when it fails in answering questions, students continue to play to be able to complete the level in the game. These actions indicate if there is an effort made by students in obtaining something. Based on the results outlined above, the Chemmo Configuration game makes the motivation to work hard from students emerge. Besides indirectly by playing the game Chemmo Configuration, students learn the chemical material Periodic System of Elements.

The third indicator aims to determine the desire of students to progress, obtain a percentage of $96 \%$. Motivation functions as a business driver and achievement achievement [6]. This is shown by the desire of students to play the Chemmo Configuration game outside of class hours, they want to be even better in understanding and mastering the Material Periodic System material. Based on the description of the explanation, the Chemmo Configuration game gives an influence in the form of motivation to want to advance to students. This desire for new needs to be maintained so that chemistry learning achievements improve.

There is a positive influence on the use of the Chemmo Configuration game on student learning outcomes. That is because the pleasant learning conditions lead to increased student motivation in learning. The high motivation of students in learning will have a good impact on student learning outcomes [9]. This is evident that all students have reached individual completeness.

\section{Student Response Results}

The results of the students' responses were obtained from the questionnaire responses given after the students used the Chemmo Configuration game as learning media presented in Table IV.

\begin{tabular}{lc} 
TABLE IV. RESULTS OF QUESTIONNAIRE RESPONSES \\
Assessed Indicator & $\begin{array}{c}\text { Percentage } \\
\text { of } \\
\text { Practicality }\end{array}$ \\
\hline $\begin{array}{l}\text { Student interest in the game. } \\
\text { Ease of understanding the } \\
\text { material and use of the } \\
\text { game. }\end{array}$ & $97,6 \%$ \\
\hline
\end{tabular}

Based on Table 4 above, it can be seen if the interest of students in learning chemistry, especially in the Periodic System of Elements using the Chemmo Configuration game is very high. Computer-based games featuring interesting multimedia make students interested in playing it until they can finally learn chemistry from the games they have played [10]. Meanwhile, the second assessment indicator also gets a high percentage of $97.8 \%$, students respond if the Material Periodic System material packaged in the Chemmo Configuration game is easy to understand as well as the use of games that are easy to follow, games easy to operate, and menus the game works fine. This result is supported by the posttest results which increase from the pretest results before using the Chemmo Configuration game as learning media. The ability to understand the material and work on the posttest questions also relates to activities carried out by students during play ie when solving questions at every level in the game. The activity is also related to the achievement of learning objectives.

\section{CONCLUSION AND SUGGESTION}

\section{A. Conclusion}

Based on the results of research and discussion.

1) The Chemmo Configuration game which was developed as a learning media for the Periodic System of Elements can complete the learning outcomes and motivate students' learning,

2) Computer-based games developed based on pedagogic requirements and game requirements can improve student learning outcomes and motivate students to learn.

3) The use of the Chemmo Configuration game has received positive responses by students, namely feeling interested and easy to use, and easy to use for learning.

\section{B. Suggestion}

Should continue to develop computer-based games guided by pedagogic requirements and game requirements to meet the needs of the game as a medium for learning chemistry. 


\section{REFERENCES}

[1] Rastegarpour, H., \& Marashi, P. (2012). The Effect of Card Games and Computer Games on Learning of Chemistry Concepts. ProcediaSocial and Behavioral Sciences, 597-601.

[2] Hidayah, R., Suprianto, \& Rahmawati, A. (2017). Permainan "Kimia Kotak Katik" Sebagai Media Pembelajaran Pada Materi Sistem Periodik Unsur. Jurnal Tadris Kimiya, 91-96.

[3] Mustakim, S., Walanda, K. D., \& Gonggo, S. T. (2013). Penggunaan QR Code Dalam Pembelajaran Pokok Bahasan Sistem Periodik Unsur Pada Kelas X SMA Labschool Untad. J.Akademika Kim, 215-221.

[4] Fatokun, Egya, \& Uzoechi. (2016). Effect of Game Instructional Approach on Chemistry Students Achievement and Retentien in Periodicity. Europan Journal of Research and Reflection in Educational Sciences, 29-40.

[5] Sardiman. 2016. Interaksi dan Motivasi Belajar Mengajar. Jakarta: Rajawali Pers.

[6] Akkuzu, N., \& Uyulgan, M. A. (2016). How To Improve Students Comprehension Concerning The Major Term of Functional Group? In The Experiment of Orcee Taboo Game. International Journal of Higher Education, 196-212.
[7] Trianto. (2010). Model Pembelajaran Terpadu Konsep, Strategi, dan Implementasinya dalam Kurikulum Tingkat Satuan Pendidikan (KTSP). Jakarta: Bumi Aksara.

[8] Lutfi, A., Suyono, Erman, Hidayah, R. (2019). Edutaiment with Computer Game as A Chemistry Learning Media. Jurnal Penelitian Pendidikan Sains. Vol 8, No. 2, Mei 2019. http://journal.unesa.ac.id/index.php/jpps/index.

[9] Arista, S., \& Poedjiastoeti, S. (2014). Kelayakan Permainan Cuthatan Kimia Sebagai Media Chemoedutainment Pada Materi Sistem Periodik Unsur. UNESA Journal of Chemical Education, 158-163.

[10] Agarwal, M., \& Saha, S. (2011). LearningChemistry Through Puzzle Based Game: Atoms to Molecule. International Conference on Emerging e Learning Technologiest and Applications, 189-193.

[11] Lutfi, A. (2017). Dokumen Mutu Untuk Pengembangan Permainan Bersarana Komputer Sebagai Media Pembelajaran Ilmu Pengetahuan Alam. Ringkasan Disertasi. Program Studi Pendidikan Sains Pascasarjana. Surabaya: Unesa.

[12] M. Young, The Technical Writer's Handbook. Mill Valley, CA: University Science, 1989. 